\title{
Mastering the English formula: Fluency development of Japanese learners in a study abroad context
}

\section{David Wood \\ Carleton University}

A common perception in English language education in Japan is that studying English abroad is the way to improve speech proficiency. An important element of speech proficiency is fluency, commonly measured by temporal variables of speech such as speed, pauses, and length of runs of speech. Evidence exists that the use of formulaic sequences, strings, and frames of words with specialized functions, mentally stored and retrieved as single words, is key to fluency. The present study is an examination of the spontaneous speech of four Japanese learners in a study abroad context in Canada. The participants' narrative retells were analyzed over six months for increased fluency and use of formulaic sequences. The results show that the participants did increase their level of fluency, and that formulaic sequences played an important part in that development. This has implications for English language programs in Japan and other EFL contexts.

海外で英語を学習することにより英語の会話力は向上する、という考えは日本の英語教育の 共通認識であるといってよい。会話力における重要な要素の一つは流暢さ(fluency) である。流 暢さは通例、速度、ポーズ、発話の長さ等、発話の時間的変異により測定される。これまで行わ れた研究により、定型表現 (formulaic sequences)一独立した語彙として記憶され使用する際に 想起される特定の機能をもつた言い回しや単語のまとまり一を使うことが流暢さを増すための鍵 となることが明らかになっている。本研究は、カナダで英語を学ぶ 4 人の日本人学習者の発話 を分析、考察したものである。学習者に物語を聞かせ、それを自分の言葉で語らせることにより データを収集した。期間は 6 ヶ月間に亘った。データは流暢さと定型表現使用の量について分 析した。その結果、確かに学習者は流暢さが増し、さらに定型表現の使用がその上達に重要な 役割を果たしたことを示していることが明らかになった。この結果に基づき外国語としての英語 教育にさまざまな示唆を行った。

JALT Journal, Vol. 29, No. 2, November, 2007 
$\mathrm{I}$ $\mathrm{t}$ is widely believed in English-as-a-foreign-language (EFL) contexts that spending time abroad in an English-speaking milieu can increase proficiency in spoken English. This notion persists in Japan, as evidenced by changes to English education guidelines in the national curriculum, increased attention to English education at the tertiary level, and the proliferation of conversation schools. Indeed, many colleges and universities offer study abroad programs in English-speaking countries, and there has been increasing attention to the perceived need for internationalization as a result of the forces of globalization and international interdependence. The Ministry of Education, Culture, Sports, Science and Technology (MEXT) states that "English abilities are important in terms of linking our country with the rest of the world, obtaining the world's understanding and trust, enhancing our international presence and furthering our nation" (MEXT, 2003, p. 1). MEXT has implemented a strategic plan which includes provisions for overseas training of teachers and an annual target of 10,000 high school students studying abroad in English (pp. 7-8).

The expected benefits of study abroad often relate to greater facility with spoken language, increased speed, and ease of communication in English-in short, increased fluency. Some research has investigated whether or how fluency gain occurs in study abroad contexts, notably influential studies by Freed (1995), Riggenbach (1991), and Segalowitz and Freed (2004). However, little work has been done with Japanese first language (L1) participants. As well, very few attempts have been made to examine the fluency-enhancing role of formulaic sequences, that is, fixed strings and frames of words such as collocations, idioms, and expressions. The present study is an examination of the development of second language (L2) speech fluency in English of Japanese L1 learners studying abroad in Canada. The study was undertaken to determine the role of formulaic sequences in L2 fluency development in a study abroad context. The spontaneous speech production of four Japanese learners of English as a second language (ESL) was analyzed for fluency gain and for evidence of how the use of formulaic sequences may have contributed to the fluency gains.

\section{Fluency}

Fluency is generally studied as a function of temporal variables of speech. Beginning with Goldman-Eisler $(1967,1972)$, and with the evolution of speech recording and analysis technology, there has been broad 
agreement on the temporal variables linked to fluency: rate or speed of speech, pause phenomena, and length of runs between pauses.

Rate of speech, measured as syllables uttered per minute or second, tends to increase over time along with other measures of fluency or to correlate with judges' perceptions of fluency (Freed, 1995; Riggenbach, 1991; Towell, 1987; Towell, Hawkins \& Bazergui, 1996).

Research has shown that pause phenomena are key markers of fluency. Pause times are longer in L2 than in L1 speech (Lennon, 1984; Möhle, 1984), and pause times in L2 speech reduce over time (Freed, 1995; Lennon, 1990a; Riggenbach, 1991). Studies of pause location in L1 compared to L2 speech (Dechert, 1980; Deschamps, 1980; Lennon, 1984), along with research correlating pause location with judgements of fluency (Freed, 1995; Riggenbach 1991; Segalowitz \& Freed, 2004) have shown that fluent speakers tend to pause at clause junctures or between nonintegral parts of a clause, rather than within clauses. This is likely due to the cognitive processing loads required by fluent speech; producing whole clauses in formulaic form, directly from long-term memory, could bypass the laborious process of controlled processing of utterances. In other words, rather than assembling speech from lexis and grammar, fluent speech may be largely produced by linking formulaic sequences and creative construction efficiently.

It has been shown that longer runs of speech between pauses are a key indicator of fluency (Freed, 1995; Lennon, 1990b; Möhle, 1984; Raupach, 1980). This may indicate that fluent speech involves the use of a large repertoire of formulaic sequences to aid in balancing skills, attention, and planning during spontaneous speech.

There is evidence that study abroad facilitates fluency. Riggenbach (1991) found that temporal variables in the speech of Chinese EFL learners correlated with native speaker judgments. Freed (1995) found that temporal aspects of fluency showed stronger improvement for term-abroad French L2 learners compared to a control group. Segalowitz and Freed (2004) found that study abroad students of Spanish L2 made greater gains in temporal aspects of speech fluency but that language contact, initial proficiency, and cognitive abilities played vital roles as well. Collentine (2004) found that study abroad in Spanish L2 may facilitate the ability to tell extended narratives and produce semantically dense language. Increased use of formulaic sequences may have played a part in the improved narratives and semantic density of the study abroad group. 


\section{Formulaic Sequences}

In 1983 Pawley and Syder noted that the purportedly infinite lexical and grammatical potential of language is not generally used, and we most often use standard phrases such as How are you? rather than more creative grammatically plausible options such as What is your current state of well being? They found it unlikely that speech is based on rule-governed formation of utterances from lexis through syntax, morphology, and phonology, given the limitations of human memory and attention.

Formulaic sequences are commonly defined as multiword units of language which, partly to maintain spontaneous speech in real-time communication, are stored in and retrieved from long-term memory as if they were single lexical units (Nattinger \& DeCarrico, 1992; Pawley \& Syder, 1983; Read \& Nation, 2004; Weinert, 1995; Wray \& Perkins, 2000). They have observable characteristics in speech: they have phonological coherence; they may be longer and more complex than other output; they can be fixed in form and used for specific situational purposes (Coulmas, 1979; Wray, 2002). Phraseologists have noted a broad range of formulaic sequences, including phrasal verbs, prepositional phrases, and more (Mel'cuk, 1998), and Altenberg (1998, p. 121) remarks that "what is perhaps the most striking impression that emerges...is the pervasive and varied character of conventionalized language in spoken discourse...from entire utterances operating at discourse level to smaller units acting as single words and phrases." Wray states that when identifying formulaic sequences in speech "it may simply be that identification cannot be based on a single criterion, but rather needs to draw on a suite of features" (2002, p. 43).

According to Wray and Perkins (2000), formulaic sequences are not composed semantically, but are holistic, like idioms and metaphors. They are also syntactically irregular in two aspects. Firstly, they cannot be syntactically manipulated; for example, there is no acceptable plural form of beat around the bush or passive form of face the music, nor is it possible to say you slept a wink or feeding you up. Secondly, in formulaic language syntactic rules are often broken, such as sequences with an intransitive verb + direct object, for example go whole hog, or other sequences which defy syntactic rules such as by and large. Nattinger and DeCarrico (1992, pp. 37-38) identified two large categories of lexical phrases: a) a pragmatically specialized subset of formulaic sequences—strings of specific lexical items, which may be grammatically standard; and b) generalized frames, which are category symbols and specific lexical items. Both categories may vary as to length, grammatical status, canonical or noncanonical 
shape, variability or fixedness, and whether there is a continuous, unbroken string of words or discontinuous, allowing lexical insertions.

Research in adult L2 acquisition has uncovered a role for formulaic sequences. Yorio (1980) found that adult learners used formulaic language to minimize effort and attention in communication. Bolander (1989), in a study of adult acquisition of Swedish, found that formulaic sequences contributed to ease and economy in learning and use. The learners used prefabricated language units containing target language structures well in advance of demonstrating that they had actually acquired the structures themselves. Bygate (1988), studying classroom EFL acquisition, found a wide range of pragmatic uses of formulas, including repetition, questioning, agreeing, confirming, clarification, and focusing attention. Ellis (1996) claims that much language acquisition involves memorized sequences and that repetition and rehearsal permit the development of long-term sequence information. This allows chunking of working memory contents to these established patterns, leading to fluent language use, freeing attentional resources for dealing with conceptualizing and meaning.

A role for formulaic sequences in fluent L2 speech has been indicated. Raupach (1984), in a study of an adult learner of French, found that formulaic sequences may express complete functions and operate as complete clauses, allowing the speaker time and attention to plan the next utterance. Dechert (1980) observed that the most fluent German students retelling a story in English L2 appeared to establish "islands of reliability" of ideas and language, around which they constructed a narrative.

Formulaic sequences serve vital functions in speech. Wray (2002, p. 97) sees them as aiding in controlling the nature and flow of information, allowing time for a continuing flow of speech to occur while the conscious mind is focused elsewhere in the communication process. Wray also notes that formulaic sequences have the function of shortening the processing route of speech by bypassing the need for assembly of components or use of short-term memory. They also help to mark the organization of spoken discourse. Moon (1998) notes that formulaic sequences exhibit a great deal of flexibility and are often genre specific.

\section{Method}

The present study was undertaken using a longitudinal, repeated measures design. Speech samples were collected on tape from participants at regular intervals six times over the course of a six-month period 
and analyzed for changes in temporal variables and learners' use of formulaic sequences.

\section{Participants}

The participants were four Japanese L1 students enrolled full-time in an intensive ESL program at a university in Canada. They were all in their early 20s; two were female, Yuka and Natsuko, and two were male, Isamu and Jun (all pseudonyms). All were at approximately an intermediate level of oral proficiency as measured by the intensive ESL program placement test given at the start of the term. The oral subtest was an unstructured interview with a teacher, eliciting mainly narrative talk, and scored holistically based on the levels in the program. The ESL program provided 24 hours of language instruction per week, six of which focused on spoken language, although without specific training in fluency. The participants also lived in homestay situations with Canadian families, which provided a naturalistic acquisition environment with rich and sustained opportunities for English input and communication outside of the ESL classrooms. All had been enrolled for at least one 12-week term prior to the study and remained in the program for two subsequent terms, meaning that they continued to receive the same rate of instruction over the six months.

\section{Samples}

Speech samples were recorded once a month over the six months of the study, with three silent animated films used as prompts. Each of the three films had only two characters; all had equally complex settings, and eight major plot movements. The film prompts were staggered at three-month intervals, with Film 1 used for the first and fourth samples, Film 2 used for the second and fifth samples, and Film 3 used for samples three and six.

- Film 1, Neighbours (McLaren, 1952, 8:00 minutes), tells the story of two neighbours living peacefully until a flower appears between them and they become possessive. After a period of escalating violence, they kill each other and lie in side-by-side graves, two flowers like the originals marking the graves.

- $\quad$ Film 2, Strings (Tilby, 1991, 10:00 minutes), tells the story of a woman and a man who enter their flats after taking the same elevator. The woman has a bath while the man downstairs prepares 
food. She sees people arrive at the man's place and hears them play music while water is trickling from the bath down into the man's apartment. He goes upstairs to see about repairing the leak, but the chandelier in his apartment breaks from the plaster and crashes. The musicians leave, the man returns home to play the violin alone, while the woman resumes her bath.

- Film 3, The Cat Came Back (Barker, 1988, 7 minutes 37 seconds), tells the story of a man tortured by a stray cat which appears at his door. He makes repeated fruitless attempts to get rid of the cat, finally attempting to blow it up with dynamite, inadvertently killing himself. His corpse falls after exploding, landing on the cat, which dies in turn. The soul of the man flies to heaven screaming as the nine souls of the cat follow him into eternity.

\section{Procedures}

The participants viewed each complete film once without pause for each sample. The content of the films was not introduced and no language help was provided nor did participants take notes. They did not write a script for their retellings and did not stop, pause, or rewind the tapes.

The samples were transcribed and SpeechStation2 speech analysis spectrograms (1997) were used to measure pauses with the lower cutoff point at .3 seconds. The tradition in fluency research has been to use .25 to .3 seconds as a lower end cutoff (Towell et al., 1996, p. 91); anything less is easily confused in a spectrogram with other speech phenomena such as the stop phase of a plosive sound, and anything longer can omit significant pause phenomena.

\section{Variables Measured}

Five temporal variables of speech were analyzed for each segment:

- $\quad$ Speech Rate (SR): Syllables uttered per minute, or the actual number of syllables uttered, divided by the total speech time in seconds. This is a gross measure of speed of speech production.

- $\quad$ Articulation Rate (AR): Syllables uttered per minute excluding pause time. This is a measure of speed of actual phonological production.

- Nonphonation/ Time Ratio (NTR): The percentage of total speech time spent pausing. This is the total pause time for each speech 
sample calculated as a percent of the total speech time. It indicates the amount of hesitation relative to actual speaking time, a combined measure of pause frequency and duration.

- Mean Length of Runs (MLR): The length of runs of speech produced between pauses, measured as the mean number of syllables uttered between pauses.

- Formula/Run Ratio (FRR): The ratio between the length of runs and the number of formulaic sequences in a sample. It is calculated as the number of runs in a speech sample divided by the number of formulaic sequences.

\section{Exemplars}

The recorded speech samples for each participant for the first and second viewing of each film were compared to see whether formulas helped to produce longer runs and fewer hesitations or clusters of dysfluncies in the second viewing compared to the earlier one after a three-month interval. Freed (1995, p. 131) defines clusters of dysfluencies as "the presence of two or more interruptions to the flow of speech." Exemplars were sought of situations in which the same element of the narrative was expressed disfluently at the first viewing and more fluently with the help of formulaic sequences at the second.

\section{Judgment of Formulaic Sequences}

Identifying formulaic sequences in the data was a central concern in this study. Corpus analysis computer software is one possible method, but reliance on frequency counts makes it difficult to determine the distribution of some types of formulaic sequences. For the present study, frequency alone cannot suffice as a criterion for identifying formulaic sequences, given the type of speech elicited. The relatively small number of samples from each participant means that some formulas may be used only once or idiosyncratically. Native speaker judgment was used to identify formulaic sequences. Some researchers such as Wray (2002, p. 23) identify some limitations of this method, such as that it may need to be used with small data sets, judgment fatigue over time may cause inconsistency, judges' decisions may vary, or it relies too much on application of intuition. These issues were addressed in the judgment procedure in the present study. With only four participants, the corpus is small, consisting of roughly 8,000 words. Inconsistency or variation among judges 
was addressed by using three judges who were graduate students in applied linguistics who had read the key literature on characteristics of formulaic sequences, and by having a benchmark judging session at the outset, after which individual judges privately continued listening to the recordings and reading transcripts to make judgment decisions at their own pace.

No particular criterion or combination of criteria were deemed as essential for a word combination to be marked as formulaic; instead five overarching criteria were applied in deciding whether a sequence was a formula:

1. Phonological coherence and reduction: In speech production formulaic sequences may be uttered with phonological coherence (Coulmas, 1979; Wray, 2002), with no internal pausing and a continuous intonation contour. Phonological reduction may be present, such as phonological fusion, reduction of syllables, and deletion of schwa, all common features of the highest-frequency phrases in English, but much less in low-frequency or more constructed utterances, according to Bybee (2002). Phonological reduction can be taken as evidence that "much of the production of fluent speech proceeds by selecting prefabricated sequences of words" (Bybee, 2002, p. 217).

2. The taxonomy used by Nattinger and DeCarrico (1992): This includes syntactic strings such as NP+Aux+VP, collocations such as curry favor, and lexical phrases such as how do you do? that have pragmatic functions (p. 36). This taxonomy is not necessarily always applicable; it was used as a guide to possible formulaicity. For example, if a sequence matched other criteria and fit into a category in this taxonomy, it might be marked as formulaic.

3. Greater length/complexity than other output: Examples would include using I would like... or I don't understand, while never using would or negatives using do in other contexts. Judges were able to see and hear the entire output of a particular participant to help in applying this criterion.

4. Semantic irregularity, as in idioms and metaphors: Wray and Perkins (2000, p. 5) note that formulaic sequences are often composed holistically, like idioms and metaphors, and not semantically. Examples of this were apparent in the background literature for the judges, and many formulas readily match this criterion. 
5. Syntactic irregularity: Formulaic sequences tend to be syntactically irregular. This criterion was readily applied to some sequences, but it was important to check syntactically irregular sequences against other criteria on this list.

Features of the recorded speech such as speed and volume changes were also used as guides.

If two or all three of the judges agreed a sequence was formulaic, it was marked as such. Idiosyncratic or nonnative-like sequences were accepted given that judging involved blending various criteria-it was agreed that nonnative-like productions which met all or most of the criteria were examples of several phenomena marginally relevant to the study. A sequence might have been stored and retrieved as a whole in misperceived form, for example what's happened instead of what happened or thanks god instead of thank god. The communicative and cognitive stress of the retell situation also might have caused this, as participants needed to recall events while creating a running narrative thus causing articulatory slips or gaps and inaccuracies in some components of the sequences. This implies that a sequence could match the criteria and still be idiosyncratic, misperceived, stored with errors, or misarticulated due to stress.

Formulaic sequences crossed a broad range, from idioms (love your neighbour, that's it, instead of) to two-word verbs (throw away, come back, let out, give up, fall down) to repeated prepositional and participial phrases (living in the same house, taking a bath, started fighting, out of the house, at the moment, in the middle).

\section{Results}

\section{Whole Group Measures}

The data for the whole group show a trend toward increased fluency over the six months as measured by the four temporal variables of speech rate (SR), articulation rate (AR), nonphonation/time ratio (NPR), and mean length of runs (MLR). The pattern of development associated with increased fluency would be higher SR, AR, and MLR, and reduced NPR; as speed increases, runs become longer, and pause times reduced. As well, the formula/ run ratio (FRR) showed a strong increase of $23.3 \%$ over the six months. Table 1 shows the whole group means for these measures. The trend is by no means linear for any measure, and it seems that the film prompt for samples 2 and 5, Strings, presented a challenge with results on some measures that complicate the overall trends over the six months. 
However, participants dealt with these challenges in interesting ways, as evidenced by the excerpts discussed below. In any case, the overall picture in the temporal data indicates that fluency did in fact increase.

Table 1. Whole group fluency measures

\begin{tabular}{|l|c|c|c|c|c|c|c|}
\hline Sample & 1 & 2 & 3 & 4 & 5 & 6 & $\% 1-6$ \\
\hline SR & 75.0 & 67.1 & 78.9 & 84.4 & 81.5 & 95.8 & $27.8 \%$ \\
\hline AR & 152 & 138.7 & 145.6 & 159.5 & 150.9 & 170 & $11.9 \%$ \\
\hline NTR & 50.2 & 50.8 & 45.2 & 46.7 & 46 & 43.8 & $-12.8 \%$ \\
\hline MLR & 3.3 & 3.0 & 3.4 & 3.8 & 3.4 & 4.1 & $22.8 \%$ \\
\hline FRR & .30 & .32 & .31 & .38 & .30 & .37 & $23.3 \%$ \\
\hline
\end{tabular}

Note. $\mathrm{SR}=$ Speech rate; $\mathrm{AR}=$ Articulation rate; $\mathrm{NTR}=$ Non-phonation $/$ time ratio; $\mathrm{MLR}=$ Mean length of runs; FRR $=$ Formula $/$ run ratio; $\% 1-6=$ Percentage change from sample 1 to sample 6 .

It is important to note that the FRR measure of the ratio of formulaic sequences to runs shows strong development over the six samples. This can be taken as an indication that participants were indeed using more formulaic sequences in producing the longer runs between pauses which indicate fluency. For more information as to how this occurred, it is necessary to examine the results of individual participants in greater detail.

\section{Individual Participant Measures and Exemplars}

The temporal measures and FRR scores by sample for each participant are presented below, accompanied by a commentary on the changes in performance over time. Also displayed for each participant are paired transcript excerpts for retellings of the same film narrative in which there is a pattern of reduction of total pause time and increase in MLR facilitated by the use of formulaic sequences. These paired excerpts are for performances separated by a time interval of three months, whereas the temporal data in the tables covers all six months of the study. In the excerpts, formulaic sequences are marked in bold italic type and pauses are indicated in parentheses by their duration in seconds. Each short transcript is followed by an indication of the total pause time, number of formulas used, MLR, and a discussion of the differences between the first and second retellings. 
Temporal measures for each participant show similar trends, although some participants showed stronger gains on some measures and more nonlinear development. As noted above, in some cases the results for samples 2 and 5, based on the film prompt Strings, distort the trends somewhat, but are nevertheless included because of the value of the discourse in those samples.

At the outset Jun was at the highest level of fluency, followed in order by Natsuko, Yuka, and Isamu. The individual results are discussed below in this descending order.

Jun

Jun shows a complex profile on the five variables. His SR scores are relatively steady over the six months, while his AR scores drop, especially in samples two and five. The film prompt for those samples was Strings, and he articulated more slowly while retelling that particular narrative. His NTR scores, however, drop over time, especially in sample three, but rise for sample four. In this case, the film prompt would not have had any influence on the pause times. His MLR grows steadily over the samples, dropping for sample two and staying level for sample five, which were based on the film prompt Strings. His FRR increases modestly and again we see the possible effect of the film Strings in his drop in FRR for samples two and five. Overall, Jun may show a film prompt effect, which makes his general fluency profile a weak fit with the goal of increased SR, AR, MLR, and FRR, with reduced PTR.

Table 2. Jun: temporal measures

\begin{tabular}{|l|c|c|c|c|c|c|c|}
\hline Sample & 1 & 2 & 3 & 4 & 5 & 6 & $\% 1-6$ \\
\hline SR & 91.1 & 79.5 & 97.3 & 91.1 & 87.4 & 98.5 & $8.1 \%$ \\
\hline AR & 205 & 175 & 185.2 & 192.2 & 181.5 & 189.2 & $-7.7 \%$ \\
\hline NTR & 55.1 & 55.3 & 47.5 & 52.4 & 52 & 48.6 & -11.8 \\
\hline MLR & 4.1 & 3.6 & 4.1 & 4.3 & 4.3 & 5.1 & $24.4 \%$ \\
\hline FRR & .56 & .47 & .51 & .58 & .47 & .57 & $1.8 \%$ \\
\hline
\end{tabular}

Note. $\mathrm{SR}=$ Speech rate; $\mathrm{AR}=$ Articulation rate; $\mathrm{NTR}=$ Non-phonation $/$ time ratio; $\mathrm{MLR}=$ Mean length of runs; FRR = Formula $/$ run ratio; $\% 1-6=$ Percentage change from sample 1 to sample 6 . 
It may be that Jun showed a reduction in AR because he articulated more slowly to allow himself to plan ahead or retrieve formulas, concepts, and creatively constructed language. He shows reduced pause time over the course of the study but little increase in length of runs. It could be that he used slower articulation instead of hesitation as a strategy to create an illusion of fluency.

He stays on the topic of narrative retell and does not tend to use selftalk formulas such as "I don't know," or "I think." He does not show evidence of avoiding difficult aspects of the narratives, except in the first two samples, which are brief and cursory general descriptions of the main thrust of the stories.

\section{Samples 2 and 5: Strings-guests arrive and begin to play music}

\section{First Attempt}

came (0.3) his house (1.4) to make music (2.5) and they played music (0.7) with (1.1) guitar (0.4) violin contrabass

6.4 sec. total pause time - 2 formulas - MLR 3.0

\section{Second Attempt}

some people will come to his house / to play music (1.5) their instruments are also strings

\section{$1.5 \mathrm{sec}$. total pause time - 3 formulas - MLR 10.0}

The second attempt deals more concisely with the content probably because Jun avoids trying to recall the names of the particular instruments. The first run is extended by linking two formulas.

\section{Natsuko}

Natsuko also shows a complex pattern of development. Her speed scores, SR and AR, increase steadily and her mean length of runs also increases somewhat. Her NTR scores fluctuate from sample to sample showing a slight decrease overall. Her FRR declines over time, indicating perhaps that any increases in her fluency profile were not due to use of formulas, but to other factors such as automatization of syntax or strategies for fluency which involve lexical devices or other language features. Her MLR increase is modest and her NTR erratic, which would seem to show that use of formulas does not account for the increase in speed variables. 
Table 3. Natsuko: temporal measures

\begin{tabular}{|l|c|c|c|c|c|c|c|}
\hline Sample & 1 & 2 & 3 & 4 & 5 & 6 & $\% 1-6$ \\
\hline SR & 89 & 73.3 & 86.9 & 94.4 & 88.5 & 113.9 & $28 \%$ \\
\hline AR & 155.8 & 121.7 & 152.1 & 154.7 & 152.3 & 187.3 & $20.2 \%$ \\
\hline NTR & 42.3 & 39.3 & 43 & 39.7 & 42 & 39.1 & $-7.6 \%$ \\
\hline MLR & 3.74 & 3.1 & 4 & 3.6 & 3.6 & 4.1 & $10.8 \%$ \\
\hline FRR & .36 & .23 & .33 & .31 & .27 & .29 & $-19.4 \%$ \\
\hline
\end{tabular}

Note. $\mathrm{SR}=$ Speech rate; $\mathrm{AR}=$ Articulation rate $\mathrm{NTR}=$ Non-phonation $/$ time ratio; $\mathrm{MLR}=$ Mean length of runs; FRR = Formula $/$ run ratio; $\% 1-6=$ Percentage change from sample 1 to sample 6 .

It is noteworthy that Natsuko's speech samples were usually the longest and most detailed of the group and that she began the research project at a relatively high level of fluency as measured by the temporal variables. By exploring details and trying to address some of the complexities of the retell task directly, she may have overextended her language and fluency ability. This would mean that she did not avoid difficult parts of the narrative or events which might have been difficult to express comfortably, leaving her to struggle, reformulate, and repair, producing clusters of dysfluencies. Furthermore, her FRR declined over the six samples, which may mean that she lacked the formulas to express what she wanted or that she became cognitively overloaded by the task of recalling what she had seen and could not use automatized chunks which she might otherwise have easily retrieved.

Natsuko's enthusiasm for detail, combined with her minimal progress in developing fluency, may stem from her investment in the task. If her desire for comprehensive retelling made her overstep her fluency abilities, this could illustrate how strong investment in speech tasks can actually be a disadvantage. Her lengthy and detailed speech samples may be evidence of investment in the process and a level of self-efficacy, but, by trying so hard, she may have pushed herself into dealing with language and concepts which outstripped her actual ability. 
Samples 3 and 6: The Cat Came Back-taking the cat to the forest

\section{First Attempt}

and (1.0) first he (1.0) um (1.5) took the cat tried to (0.5) out the cat (0.4) in the forest (1.2) by car (0.3) but the cat (0.5) um returned the house (2.2) came back the house (2.6) faster than him

11.2 sec. total pause time - 5 formulas - MLR 3.09

\section{Second Attempt}

I forget / I forget the order but maybe the $\mathrm{f}$ he went to the forest first (0.6) and ah (0.3) to put it (0.4) put it (0.3) in the forest, leave it (0.7) but (0.6) ah (1.0) he couldn't make it (0.3) cause the (0.9) um (2.8) before he (0.6) he went back to his car (0.4) the cat already came back to his car and ah

\section{9 sec. total pause time - 8 formulas - MLR 5.0}

In this case, Natsuko produces a much more fluent description in the second attempt while adding a comment about her difficulty recalling it. Although still dysfluent in runs 2 to 4,6 and 7, and 9 to 11, she uses formulas to extend runs and express herself more efficiently. Pausing is reduced and MLR increased. The formulas are simple and the last two contain a common lexical element back, effectively relating the events, and perhaps triggered by the title of the film, The Cat Came Back.

\section{Yuka}

Yuka's profile on all variables is complex. She performed the poorest on sample five on all variables, and her NTR scores show increased rates of pausing over time. However, she managed a strong increase in formula-run ratio over time. While her data are not a model of the pattern which shows steady development of fluency, she did demonstrate improvement in some aspects.

She sometimes digressed from straightforward narrative retell to comment on other issues. In sample four she makes lengthy reference to the September 11th terrorist attacks in New York. Sample four is brief and she focuses on the actual retell for less than half of the speech time. In sample two she comments several times that she doesn't understand. This may account for her decrease in fluency for that sample, but also, it may account for the fact that she shows a large increase in FRR for sample two. Formulas such as "I don't understand," "I don't know," and "I'm sorry" add to the number of formulas but do not facilitate the actual retell of the narrative itself. 
Table 4. Yuka: temporal measures

\begin{tabular}{|l|c|c|c|c|c|c|c|}
\hline Sample & 1 & $\mathbf{2}$ & $\mathbf{3}$ & $\mathbf{4}$ & $\mathbf{5}$ & $\mathbf{6}$ & $\mathbf{\%} \mathbf{1} \mathbf{- 6}$ \\
\hline SR & 61.5 & 56.6 & 72 & 77.8 & 53.9 & 65 & $5.7 \%$ \\
\hline AR & 134.9 & 136.9 & 147.3 & 158.5 & 114.9 & 152.7 & $13.2 \%$ \\
\hline NTR & 54.4 & 58.7 & 51 & 51.1 & 53 & 57.3 & $-5.3 \%$ \\
\hline MLR & 2.83 & 2.52 & 3 & 3.7 & 1.78 & 3 & $7.1 \%$ \\
\hline FRR & .22 & .45 & .33 & .40 & .31 & .38 & $72.7 \%$ \\
\hline
\end{tabular}

Note. $\mathrm{SR}=$ Speech rate; $\mathrm{AR}=$ Articulation rate $\mathrm{NTR}=$ Non-phonation $/$ time ratio; $\mathrm{MLR}=$ Mean length of runs; FRR = Formula $/$ run ratio; $\% 1-6=$ Percentage change from sample 1 to sample 6 .

The uneven pattern of development in Yuka's speech may be due to issues of self-efficacy and language anxiety. Yuka was among the lowest performers at the beginning of the research project and, as lacking a sense of voice or power, she struggled with each retelling and may have been less invested in the process,.

The variations in which narrative elements or themes Yuka chose to deal with make it impossible to directly compare segments of her narratives. However, the ends of her samples based on film 1 Neighbours show greater fluency and a change in her use of formulaic sequences.

\section{Samples 1 and 4: Neighbours-end of the story/theme}

\section{First attempt}

but last (2.5) they are (0.8) died (1.2) there is nothing (1.5) th (2.0) after the fight (2.5) they can't (1.5) gain (0.5) anything (1.5) without died.

$14 \mathrm{sec}$. total pause time - 3 formulas - MLR 2.3

\section{Second attempt}

I think world (0.3) war is biggest (1.0) accident in the (1.3) world (0.7) or in the earth (2.5) but I don't know how should I do (1.2) but we have to (0.3) stop (0.7) that things

8 sec. total pause time - 4 formulas - MLR 3.5

Yuka is communicating something different in the second attempt. Rather than simply retelling the scene from the film as in the first attempt, 
she extrapolates on the theme. While expressing this more complex content, she is still able to produce longer runs and avoid lengthy hesitations. She uses more formulaic sequences to do so, including an idiosyncratic formula how should I do. She is probably able to simultaneously control content and production in the second attempt because she is expressing her feelings rather than struggling to recall events and recount them directly.

Isamu

Isamu shows development in all variables to fit the profile of increased fluency and formula automatization. His speed scores and NTR show good development, especially in the last three samples. However, his MLR scores level off for those same samples. His FRR development shows variation over the samples but more than tripled from sample one to sample six.

Table 5. Isamu: temporal measures

\begin{tabular}{|l|c|c|c|c|c|c|c|}
\hline Sample & 1 & 2 & 3 & 4 & 5 & 6 & $\% 1-6$ \\
\hline SR & 58.4 & 59 & 59.5 & 74.4 & 96.2 & 105.9 & $81.3 \%$ \\
\hline AR & 112.3 & 121 & 97.6 & 132.6 & 154.8 & 150.9 & $34.4 \%$ \\
\hline NTR & 49 & 49.9 & 39.4 & 43.5 & 37 & 30 & $-38.8 \%$ \\
\hline MLR & 2.7 & 2.6 & 2.5 & 3.7 & 3.8 & 4.2 & $55.6 \%$ \\
\hline FRR & .06 & .12 & .07 & .22 & .16 & .25 & $316.7 \%$ \\
\hline
\end{tabular}

Note. $\mathrm{SR}=$ Speech rate; $\mathrm{AR}=$ Articulation rate; $\mathrm{NTR}=$ Non-phonation $/$ time ratio; $\mathrm{MLR}=$ Mean length of runs; FRR $=$ Formula $/$ run ratio; $\% 1-6=$ Percentage change from sample 1 to sample 6 .

Like Yuka, Isamu shows a tendency to talk about issues related to the topic or themes of the films in addition to direct retelling of the narratives. For example, in sample four he reflects on the September 11th terrorist attacks at length, and in sample five he comments at length on the unusual floor plans of the apartments depicted in the film. Unlike Yuka, however, he manages to progress on all temporal aspects of fluent speech over all six samples. His speech samples are all relatively brief, and he is generally cautious to retell only the main narrative moves without detail. 
Isamu may be an example of an L2 speaker who has limited language ability but enough investment in the process of trying to speak that he uses discourse strategies to appear fluent. He avoids conceptually or linguistically challenging content and injects his own opinions and observations into the task. While he was clearly among the least fluent participants at the start of the research project, he showed steady improvement as time passed. Unlike Yuka, he was able to perform the task without being overwhelmed each time, and unlike Natsuko, he chose what to express most efficiently. It may be that he lacked language anxiety and had a sense of investment which helped him overcome his language limitations.

\section{Samples 3 and 6: The Cat Came Back-suicide and pursuit by souls of the cat}

\section{First Attempt}

she dead (1.0) and (0.5) then (0.5) they happy because (0.3) they (0.5) separate (0.7) ah (1.0) by (1.0) cat (0.7) cat (1.0) die dead (0.9) and she unhappy (2.5) ah (0.5) then (0.5) many cat (1.0) she go (1.5) he (0.5) go to (1.3) heaven with (0.5) many cat (0.4) she very cry

$\mathbf{1 6 . 8} \mathrm{sec}$. total pause time - 0 formulas - MLR 2.10

\section{Second Attempt}

and then he dead (1.0) yeah (0.5) and then but ah (0.8) next nonsense (0.5) why cat (1.0) cat dead but (0.8) cat spirit is (0.5) just nine (0.5) ah a lot of ni it's ah nine (0.5) spirits (1.0) so (1.0) terrible he grow up

\section{1 sec. total pause time - 4 formulas - MLR 3.33}

Isamu's initial attempt consists of one- or two-word runs and many lengthy hesitations-almost one large cluster of dysfluency. In the second attempt, he improves fluency with several simple formulas and more direct and concise description. This increases MLR and reduces pausing significantly. He makes use of the rhetorical device and then to lengthen runs and mark the sequence which helps him buy time in articulation as it is repeated after a long pause. This may create an illusion of fluency as he tries to recall the next event or formulate the next stretch of language.

\section{Conclusion}

The results of the study indicate the participants as a group experienced fluency gain as expected in a study abroad context. The paths taken 
by the individual participants are quite varied, however, whether measured quantitatively or by an analysis of the discourse. Human discourse is complex and influenced by situational and affective forces, including amount and quality of language contact in a study abroad situation and classroom experience (Segalowitz \& Freed, 2004). Several themes emerge from the data in the present study. Participants used formulas to extend the length of runs and give concise expression to events in the narratives. By doing so, they were in some cases able to eliminate all or part of the dysfluency evident in earlier retells of the same film. Even in cases involving the especially challenging film prompt Strings, participants were able to use formulas to navigate the discourse more effectively and efficiently in the second retelling. Pause times and frequencies are reduced as well in most instances in the second retells, as the use of formulaic sequences facilitated expression. In some instances, the second retelling of a film segment included extra or more complex content, but nevertheless the participants were able to communicate more efficiently by using formulas. In several cases retrieval of a key lexical item in retell number two is followed by a brief pause and a formula containing the key item, uttered coherently and quickly: an indicator of automatic retrieval as the lexical item may have triggered retrieval of the whole formula.

The factors which may have facilitated the acquisition and use of formulaic sequences in these speech productions are not readily apparent in the data, nor is there a firm set of theoretical or empirical knowledge in the literature to guide an interpretation. No doubt the participants benefited from input and experience over the months of the study in an English language environment although to varying degrees. It may be that the participants attended to formulaic sequences in the classroom, had exposure and practice with them in classroom tasks, or had encountered them prior to arriving in the university intensive program. As previous research has suggested, language contact, cognitive factors, and initial proficiency play a role in the development of fluency in study abroad situations (Segalowitz \& Freed, 2004).

In any event, in the present study participants used more formulaic sequences in later speech productions, enhancing their fluency. They may have stored them by any variety of means based on their frequency, utility, or surface features. They may have retrieved them in a range of ways from automatic single-step (triggered by pragmatic aspects of the speech situation) to conscious and controlled (based on meta-awareness of content requirements). Clearly, further research is needed, using a broader range of discourse types including dialogic conversation, but, based on 
the results of the present study, a case can be made for a broad experience with spoken language as being an important element in enhancing speech fluency in EFL.

It appears that the use of formulaic sequences can be important to the development of fluency in L2 speech and that experience in a study abroad context can indeed aid learners in achieving the goal of fluency gain. Perhaps the common belief in Japan that studying English abroad is the way to improve speech ability is correct. It may be time for Japanese English language educators and planners to attempt to incorporate a study abroad component in English programs or to find ways to augment classroom instruction with increased contact with native speakers by electronic or other means.

\section{Acknowledgments}

The author wishes to thank the participants in this study and the two anonymous JALT Journal reviewers, whose input was extremely helpful in the crafting of this paper.

David Wood has been working in the language education field for many years, currently as Assistant Professor of Applied Language Studies at Carleton University, Ottawa, Canada. He has taught applied linguistics at the University of Victoria and in Japan at Naruto University of Education. His research interests are formulaic sequences, spoken language, and teacher education.

\section{References}

Altenberg, B. (1998). On the phraseology of spoken English: The evidence of recurrent word-combinations. In A. P. Cowie (Ed.), Phraseology: Theory, analysis, and applications (pp. 101-122). Oxford: Clarendon.

Barker, C. (Director). (1988). The cat came back [Motion Picture]. Montreal: National Film Board of Canada.

Bolander, M. (1989). Prefabs, patterns, and rules in interaction? Formulaic speech in adult learners' L2 Swedish. In K. Hyltenstam \& L. K. Obler (Eds.), Bilingualism across the lifespan: Aspects of acquisition, maturity, and loss (pp. 7386). Cambridge: Cambridge University Press.

Bybee, J. (2002). Phonological evidence for exemplar storage of multiword sequences. Studies in Second Language Acquisition, 24, 215-221.

Bygate, M. (1988). Units of oral expression and language learning in small group interaction. Applied Linguistics, 9 (1), 59-82. 
Collentine, J. (2004). The effects of learning contexts on morphosyntactic and lexical development. Studies in Second Language Acquisition, 26, 227-248.

Coulmas, F. (1979). On the sociolinguistic relevance of routine formulae. Journal of Pragmatics, 3, 239-266.

Dechert, H. W. (1980). Pauses and intonation as indicators of verbal planning in second-language speech productions: Two examples from a case study. In H. W. Dechert \& M. Raupach (Eds.), Temporal variables in speech (pp. 271-285). The Hague: Mouton.

Deschamps, A. (1980). The syntactical distribution of pauses in English spoken as a second language by French students. In H. W. Dechert \& M. Raupach (Eds.), Temporal variables in speech (pp. 255-262). The Hague: Mouton.

Ellis, N. C. (1996). Sequencing in SLA: Phonological memory, chunking, and points of order. Studies in Second Language Acquisition, 18, 91-126.

Freed, B. F. (1995). What makes us think that students who study abroad become fluent? In B. F. Freed (Ed.), Second language acquisition in a study abroad context (pp. 123-148). Philadelphia: John Benjamins.

Goldman-Eisler, F. G. (1967). Sequential temporal patterns and cognitive processes in speech. Language and Speech, 10 (2), 122-132.

Goldman-Eisler, F. G. (1972). Pauses, clauses, sentences. Language and Speech, 15 (2), 103-113.

Lennon, P. (1984). Retelling a story in English. In H. W. Dechert, D. Möhle, \& M. Raupach (Eds.), Second language productions (pp. 50-68). Tubingen, Germany: Gunter Narr Verlag.

Lennon, P. (1990a). The advanced learner at large in the L2 community: Developments in spoken performance. International Review of Applied Linguistics in Language Teaching, 28, 309-321.

Lennon, P. (1990b). Investigating fluency in EFL: A quantitative approach. Language Learning, 40, (3), 387-417.

McLaren, N. (Director). (1952). Neighbours [Motion Picture]. Montreal: National Film Board of Canada.

Mel'cuk, I. (1998). Collocations and lexical functions. In A. P. Cowie (Ed.), Phraseology: Theory, analysis, and applications (pp. 23-53). Oxford: Clarendon.

Ministry of Education, Culture, Sports, Science, and Technology (MEXT). (2003). Regarding the establishment of an action plan to cultivate "Japanese with English abilities." Tokyo: Ministry of Education, Culture, Sports, Science and Technology.

Möhle, D. (1984). A comparison of the second language speech production of different native speakers. In H. W. Dechert, D. Möhle, \& M. Raupach (Eds.), Second language productions (pp. 26-49). Tubingen: Gunter Narr Verlag.

Moon, R. (1998). Frequencies and forms of phrasal lexemes in English. In A. P. Cowie (Ed.), Phraseology: Theory, analysis, and applications (pp. 79-100). Oxford: Clarendon. 
Nattinger, J. R., \& DeCarrico, J. S. (1992). Lexical phrases and language teaching. Oxford: Oxford University Press.

Pawley, A., \& Syder, F. H. (1983). Two puzzles for linguistic theory: Nativelike selection and nativelike fluency. In J. C. Richards \& R. W. Schmidt (Eds.), Language and communication (pp. 191-226). New York: Longman.

Raupach, M. (1980). Temporal variables in first and second language speech production. In H. W. Dechert \& M. Raupach (Eds.), Temporal variables in speech (pp. 263-270). The Hague: Mouton.

Raupach, M. (1984). Formulae in second language speech production. In H. W. Dechert, D. Möhle, \& M. Raupach (Eds.), Second language productions (pp. 114137). Tubingen, Germany: Gunter Narr Verlag.

Read, J., \& Nation, P. (2004). Measurement of formulaic sequences. In N. Schmitt (Ed.), Formulaic sequences: acquisition, processing, and use (pp. 23-35). Amsterdam: John Benjamins.

Riggenbach, H. (1991). Toward an understanding of fluency: A microanalysis of nonnative speaker conversations. Discourse Processes, 14, 423-441.

Segalowitz, N., \& Freed, B. F. (2004). Context, contact, and cognition in oral fluency acquisition: Learning Spanish in at home and study abroad contexts. Studies in Second Language Acquisition, 26, 173-189.

SpeechStation2 [Computer software]. (1997). Somerville, MA: Sensimetrics Corporation.

Tilby, W. (Director), \& Verrall, D. (Producer). (1991). Strings [Motion Picture]. Montreal: National Film Board of Canada.

Towell, R. (1987). Variability and progress in the language development of advanced learners of a foreign language. In R. Ellis (Ed.), Second language acquisition in context (pp. 113-127). Toronto: Prentice-Hall.

Towell, R., Hawkins, R., \& Bazergui, N. (1996). The development of fluency in advanced learners of French. Applied Linguistics, 17 (1), 84-119.

Weinert, R. (1995). The role of formulaic language in second language acquisition: A review. Applied Linguistics, 16, (2), 180-205.

Wray, A. (2002). Formulaic language and the lexicon. Cambridge: Cambridge University Press.

Wray, A., \& Perkins, M. R. (2000). The functions of formulaic language: An integrated model. Language and Communication, 20, 1-28.

Yorio, C. (1980). Conventionalized language forms and the development of communicative competence. TESOL Quarterly, 14 (4), 433-442. 